\title{
Yerel Firmaların Markalama Sürecinde Dijital Reklamcılık Deneyimi: Vavin Örneği'
}

\author{
Nilgün Tuzcu² \\ Șefika Özdemir ${ }^{3}$ \\ Hatice Baysal ${ }^{4}$
}

\begin{abstract}
Öz
Dijitalleşme ve yeni iletişim teknolojileri insanların fikirlerini, duygularını ve düşüncelerini içeren resim, görüntü ve yazı paylaşmalarını sağlayan sosyal medya ortamını sunmaktadır. Günlük yaşamın ayrılmaz bir parçası haline gelen sosyal medya, tüketicilerin eğlenme, öğrenme, alışveriş ve iletişim ihtiyaçlarını karşılamak üzere kullanılmasının yanı sıra birbirleriyle iletişim kurmalarını, markalar hakkında rahatlıkla bilgi edinebilmelerini, deneyimlerini ve şikâyetlerini paylaşmalarını sağlayan popüler çevrimiçi araçlar sunmaktadır. Çift yönlü iletişime imkân veren ve içerik üretimleriyle tüketicilerin katılımını arttıran bu araçlar birer iletişim ve reklam kanalı olarak hedef kitlenin belirlenmesinde ve doğrudan tüketiciye ulaşmada markalar açısından stratejik rol oynamaktadır.
\end{abstract}

Sosyal medya pazarlama stratejileri açısından, özellikle küçük ölçekli/yerel işletmeler için düşük maliyetler, müşteriye yönelik içerik üretiminde esneklik ve hız avantajı sağlaması, kişiselleştirmeye imkan vermesi ile rekabet avantajı yaratmaktadır. Bu çerçevede, üretilen dijital reklamlar, özel günlere yönelik kampanyalar, viral reklamlar, sanal vitrin uygulamaları, oyunlaştırmalar ve deneyimsel reklamlar gibi uygulamalar markalama sürecinde kullanılmaktadır.

Araştırmada, tekstil sektöründe faaliyet gösteren yerel bir firmanın markalama sürecinde kullandığı dijital reklam stratejileri incelenmiştir. Bu bağlamda, kullanılan sosyal medya araçları, bu araçlar için üretilmiş olan tanıtım materyalleri, takipçi sayıları, güncelleme süreleri, alınan geri bildirimler, reklam bütçeleri çerçevesinde firmadan görüşme yöntemiyle elde edilen bilgilere içerik çözümlemesi uygulanmıştır.

Elde edilen bulgular firmanın uyguladığı dijital reklam stratejilerinin markalama sürecine olumlu katkı sağladığını işaret etmektedir.

Anahtar Kelimeler: Sosyal Medya, Markalama, Dijital Reklamcılık

1 Bu çalışma, 1-3 Kasım 2018 tarihleri arasında Akdeniz Üniversitesi İletişim Fakültesi tarafından düzenlenen 3. Uluslararası Medya Çalışmaları Sempozyumunda sözlü bildiri olarak sunulmuştur.

2 Doktorant, Süleyman Demirel Üniversitesi Sosyal Bilimler Enstitüsü İşletme Anabilim Dalı, nilguntuzcu@ hotmail.com

3 Dr. Öğr. Üyesi, Süleyman Demirel Üniversitesi İletişim Fakültesi Halkla İlişskiler ve Tanıtım Bölümü, sefikaozdemir@sdu.edu.tr

3 Dr.Öğr.Üyesi, Süleyman Demirel Üniversitesi İletişim Fakültesi Yönetim ve Organizasyon Bölümü, haticebaysal@sdu.edu.tr 


\title{
Digital Advertising Experience In The Branding Process of Local Firms: Vavin Sample
}

\begin{abstract}
Digitalization and new communication Technologies offer a social media environment that allows people to share their images, photos, texts and their ideas, emotions and thoughts. Social media, which has become an inseparable part of everyday life, in addition to being used to meet the entertainment, learning, shopping and communication needs of consumers, provide popular online tools that enable consumers to communicate with each other, easily get information about brands, share their experiences and complaints. These tools that allow two-way communication and increasing participation of consumers through content production as a channel of advertising and communication, plays a strategic role in terms of brands especially when it come to determination of target audience and directly reaching to consumers. Social media create a competitive advantage in terms of marketing strategies, especially for small-scale / local businesses by providing low cost, flexibility and speediness in content production for customer and customization. In this context, applications such as digital advertisement special day campaigns, viral advertisement, virtual showcase applications, gamification and experiential advertisements are used in the branding process. In this study, digital advertising strategies used in the branding process of a local company operating in the textile sector was examined. Content analysis was applied to information obtained with interview from the company in the framework of social media tools, promotional materials produced for these tools, the follower numbers, update times, received feedbacks and advertising budgets. The findings indicate that the firms' digital advertising strategies have contributed positively to the branding process.
\end{abstract}

Keywords: Social Media, Branding, Digital Advertising

Atıf: Tuzcu Nilgün vd. (2018) Yerel Firmaların Markalama Sürecinde Dijital Reklamcılık Deneyimi: Vavin Örneği. Akdeniz Üniversitesi İletișim Fakültesi Dergisi, (AKiL) Kasım (30) s. 374-392 


\section{Giriș}

$\mathrm{B}$ ilgi ve iletişim teknolojilerinde yaşanan gelişmelerle birlikte pazarlama dünyası çok daha dinamik bir çevreye kavuşmuş; tüketicilerin davranışları, işletmelerin faaliyetleri ve stratejileri ortaya çıkan yeniliklerle birlikte hızla değişmektedir. Rogers (2003), yeniliği bireyler ya da işletmelerin gereksinimlerini karşılamada problemlere alternatif çözümler geliştirmek veya gereksinimi algılamada yeni yollar bulma olarak değerlendirmektedir. İşletmeler değişen koşullarla birlikte ortaya çıkan gereksinimleri karşılayabilmede teknolojiyi takip etme ve uyum sağlama becerileri önemli rol oynamaktadır. İşletmelerin bu yeniliklere uyum sağlaması bilgiye erişim düzeyleri, öğrenme ve hızı karar alma becerilerine bağlıdır. Bunu Rogers (2003) Teknolojinin yayılmasını sosyal bir değişim olarak değerlendirerek Yeniliğin Yayılması modelinde, yeniliği bireyler ya da işletmeler için yeni bir ürün, bakış açısı, teknoloji yada çözüm yolu olarak tanımlamaktadır. Davis (1989), bireylerin yaşamlarında ve iş yapmalarında teknolojik yeniliklerin kullanışlılık ve fayda sağladığına inanmalarının teknolojik yenilikleri kabul etmelerinde etkili olduğunu belirtmektedir. Bu bağlamda ele alındığında günümüzde İnternete erişimin yaygınlaşması ve internetin gündelik hayatın önemli bir parçası olmasıyla birlikte tüketicilere ulaşma noktasında dijital ortamlar önemli hale gelmiştir.

Tüketicilerin kendi ağlarını kurmalarına ve sanal paylaşıma imkân veren, sürekli kendini güncelleyebilen, etkileşimli ve çift yönlü iletişim sunan sosyal medyanın ortaya çıkmasıyla birlikte işletmeler bu platformlar üzerinden reklamcılık faaliyetlerini gerçekleştirmeye başlamışlardır. Özellikle görselliğin ön planda olduğu, eğlendirici, ilgi çekici ve içeriği farklı bir şekilde sunan platformlar internetin aktif kullanıcıları olan genç ve dinamik kuşağın dikkatini daha fazla çekmekte ve zihinlerinde kalmaktadır. Sosyal medyayı etkin kullanan markalar dijital reklamlar sayesinde markalarını sürekli görünebilir hale getirebilmektedir. Öte yandan, dijital reklamlar ana akım medya reklamları ile de desteklenebilmektedir.

Dijital reklamcılık ölçümlenebilirlik ve kişiselleştirme açısından önemli avantajlar sunması nedeniyle işletmeler tarafından tercih edilmektedir. Bu kapsamda Facebook ve Google gibi reklam yapılan ortamların sağladığı panellerden reklam kampanyalarının başarısı, maliyeti ve hedeflenen dönüşümlere ilişkin raporlar ve analizler elde edilmektedir. Yayınlanan reklam üzerinden dijital ortamları ziyaret eden kullanıcıların hangi sayfalarda vakit geçirdiği ve hangi içerik ile daha çok etkileşime geçtiğine ilişkin davranışları analiz edilebilmektedir. Bu veriler doğrultusunda uygun müşteriye kişiselleştirilmiş ve doğru içerikte reklam mesajları gönderilmektedir.

İşletmelerin markalaşma sürecinde müşteri beklentilerini ve eğilimlerini doğru bir şekilde ve zamanında tespit ederek uygun stratejileri tasarlaması önemlidir. İşletmenin hedef kitlesinin ayırıcı özelliklerini, istek ve ihtiyaçlarını göz önünde bulunduran, müşteri ile arasında duygusal bağ oluşturabilen, dijital ortamları en iyi şekilde kullanabilen ve müşteri memnuniyetine önem veren markalar rekabette üstünlük sağlayarak markalaşma sürecinde başarılı olmaktadır. 
Tüm bunlardan hareketle yapılan bu araştırmada; yerel bir işletme iken ulusal bir işletme haline gelen "Vavin Giyim" markasının kısa sürede ulusal bir marka haline gelmesini sağlayan pazarlama stratejileri, kullanılan dijital reklamlar ve markalama sürecine etki eden faktörler incelenerek, ulaşılan bulguların yeni girişimcilere veya markalamada başarılı olmak isteyen işletmelere yol göstermesi beklenmektedir.

\section{Dijital Reklamcılığın Gelișimi ve Markalama}

Gelişen teknolojilerin sunduğu fırsatlarla birlikte yoğun rekabet ortamı ve arz fazlalığı şirketlerin pazarlama stratejilerini dijital ortamlara taşımasına neden olmuştur. Bunun bir yansıması olarak da reklam bütçelerinin arttığı ve marka iletişiminin stratejik bir rol üstlendiği görülmektedir (Ertemel, 2016:31). Reklamcılar Derneği'nin Deloitte işbirliğiyle hazırladığı "2017 Medya ve Reklam Yatırımları Raporu”na göre; Türkiye'de dijital mecralara yapılan medya yatırımları bir önceki yıla göre \%19, 7 yükselmiştir. Dijital mecralar 2017 yılında dünya genelinde reklam yatırımlarındaki büyümenin lokomotifi olarak görülmektedir (Deloitte, 2018:4-6).

İnternet, elektronik mesajlaşma, çevrimiçi arama, sosyal medya, mobil iletişim ve oyun ortamlarında meydana gelen gelişmeler dijital reklamcılığı ortaya çıkarmıştır (Çıvgın, 2018; Özkundakçı, 2012: 156).Geleneksel reklamcılıkta pasif konumda, sunulan kadar bilgiyi alan tüketiciden, reklamın etkileşim düzeyine göre tüketicinin istediği kadar bilgiyi sunan dijital reklamcılık uygulamalarında değişim yaşanmıştır (Lombard ve Duch, 2017:169). Yeni medyanın etkileşimli teknolojileri, tüketicilere daha iyi bir marka deneyimi sunarken tüketici davranışları üzerinde daha fazla etki yaratmaktadır (Taylor 2009).Dijital mecralar insanların gerçek kullanıcı deneyimi yaşamasını yani katılımı sağladığı için tercih edilmektedir (Sevinç, 2012: 25).

Dijital dönüşümün ilk izlerini internet üzerinden 1969 yılında gönderilen ilk mesaj servisinde görmek mümkündür. Tarihsel süreçte 1971 yılında e-posta gönderimini, 1980'li yıllarda ilk web sitesinin kurulması takip etmiştir. 90'ı yılların başları kişiye özel pazarlamaya imkan veren tarayıcı tabanlı çerezlerin kullanıldığı, e-ticaret siteleri ve banner reklamların görüldüğü bir dönemdir. 90’’ yılların sonu ise dijital alana yapılan yatırımlar ve kurulan web site sayısının oldukça artı̆̆ı; aynı zamanda Google, e-bay ve Yahoo gibi arama motorlarının ortaya çıktığı bir dönem olmuştur (Gökşin,2017). 2000'li yıllarla birlikte reklamcılık etkileşim, kişiselleşme ve katılım açısından evrilmiştir (Lombard ve Synder-Duch2017:169).

Dijital reklamcılığın son 15 yıldaki gelişimine bakıldığında üç büyük eğilimden bahsetmek mümkündür; arama motoru, sosyal medya ve mobil uygulamalar. İlk sosyal medya siteleri Friendster ve MySpace'in kuruluşu, Apple'ıniTunes mağazalarını açması ve Skype'nin video görüşmelerinde köklü değişim yaratması gibi yeniliklerin sonucunda dijital reklamcılıkta "advergame"ler gibi zenginleştirilmiş medya uygulamaları ortaya çıkmıştır. (Thorson ve Tham, 2017: 61-74). 2000'den itibaren Google arama sonuçlarında reklam gösterimi yapan AdWords uygulaması ile daha etkili ve ölçülebilir reklam sonuçlarına ulaşılmıştır. 2004 yılı ve sonrasında facebook, twitter ve instagram 
gibi sosyal medya araçlarının ve video paylaşım sitesi Youtube'un gündelik hayatta yoğun bir şekilde kullanılmasıyla bu alanlar yeni reklam mecraları olarak kullanılmaya başlanmıştır(Gökşin, 2017; Elden ve Makal, 2014, 446-447;Varnalı vd.,2011).

Sosyal medyanın ve mobil reklamcılığın gelişimi dijital reklamcılığa yön veren iki önemli değişim olarak görülmektedir (Chaffey ve Smith, 2013:16-19). Mobil reklamcılık, pazarlama yöneticilerinin mekânsal veya kablolama kısıtlaması olmaksızın, gerçek zamanlı olarak bireysel tüketicilerle doğrudan bağlantı kurmasını sağlamaktadır. Mobil reklamcılığın en önemli avantajı, telefonların SiM akıllı kartlarını bir mobil veri tabanı olarak kullanarak, tüketicilerin tanımlanmasını ve özelleştirilmiş uygulama sunumu sağlamasıdır. Bu daha kişiselleştirilmiş ve hedefli mobil reklamcılığı mümkün kılmıştır (Truong ve Simmons, 2010: 243-244).1992 yılında kısa mesaj hizmetiyle başlayan mobil reklamcılık uygulamaları 2007 yılında iPhone'un lansmanı ve akıllı telefonların kullanımının yaygınlaşmasıyla Ems, Mms, Ivr, Video Ivr, lokasyon-bazlı mesaj gönderimleri ve QR Kod kullanımları gibi farklı uygulamalarla sürekli kendini yenilemektedir (Varnalı vd., 2011: 1-43;Hopkins ve Turner, 2012: 73-85). Akıllı telefonlar ve tabletlerden internet erişiminin sağlanmasıyla birlikte kişisel bilgi, resim, video, profil ve içerik paylaşımı sağlayan sosyal ağ sitelerinde sürekli yeni bilgiler üretilmektedir (Aslan,2018: 233). Öyle ki bu üretimde mobil uygulamalar aracılığıyla video konferans, lokasyon bazlı gerçek zamanlı kuponlar, reklam amaçı olarak konum algılayıcılar ve kameralar kullanılmaktadır (Berman,2012: 16-17). Dijital reklamcılık, tüketicilerle çeşitli ve ilgili yollarla bağlantı kuran heyecan verici platformlar sunmaktadır. Ancak asıl olan teknolojiyi anlamak değil insanları daha iyi tanımak, anlamak, katılımlarını ve bilgilenmelerini sağlamak üzere teknolojiyi en iyi şekilde kullanmaktır (Ryan ve Jones, 2009: 12-13).

\section{Markalama Sürecinde Kullanılan Dijital Reklamcılık Araçları}

Temel dijital reklam araçlarını: Internet tabanlı reklamlar (web sitesi reklamları, arama motoru reklamları, arama motoru optimizasyonu, yeniden pazarlama reklamları, e-posta reklamları); mobil cihazlarda yer alan reklamlar (SMS, MMS, QR Kodları, IVR, Lokasyon-Bazlı); oyun hedefli reklamlar (eğlendirici reklam/oyunlu reklam ve oyun içi reklamlar) ve sosyal medya reklamları (sosyal ağlar, sosyal imleme siteleri, dosya paylaşım siteleri, bloglar, mikrobloglarve forumlar) olarak dört temel sınıfta gruplandırmak mümkündür (Varnalı, 2013; Öztürk, 2013; Yılmaz ve Erdem, 2016; Kuş, 2016).

Bir markanın varlığını tüketiciye hissettirebilmek, müşteriyle etkileşimde daha fazla bulunabilmek ve reklam kampanyaları gerçekleştirebilmek adına markanın mutlaka bir kurumsal web sitesinin olması gereklidir. Düzgün, anlaşılır ve göze hitap eden bir tasarıma sahip ön yüz, siteye her girildiğinde çekiciliğini kaybetmeyen, dikkat çekici renkler ve tasarımlara sahip web siteleri marka imajı oluşturmak ve markayı güçlendirmek açısından kurumların fiziki adresleri kadar önem teşkil etmektedir (Sutherland ve Sylvester, 2004: 324). Kurumsal web siteleri işletmeler açısından potansiyel ve yeni tüketiciler ile etkileşime geçme aşamasında önemli araçlardan biridir. 
İşletmeler, internet kullanıcılarını kendi sitelerine yönlendirmek için SEM (Search Engine Marketing) ve SEO (Search Engine Optimization) araçlarını kullanmaktadır. Bir web sitesi sayesinde bir markayı tanıtmak, sitenin trafiğini ve bilinirliğini artırmak, tüketicide olumlu marka imajı yaratmak, bir web sitesinin trafiğini ölçümlemek SEM ve SEO'nun görevleri arasındadır (Aslantaş, 2013, Barışkan, 2015).

Arama motorlarında hem mobil hem de masaüstü arama sonuçlarında öncelikli olmak veya üst sıralara çıkmak isteyen işletmelerin müşterilerini anlamaları ve müşterileri etkileyici içerik üretmeleri, güncelliğini korumaları, özgün olmaları, çağı yakalamaları ve teknolojiyi takip etmeleri gerekmektedir (MeermanScott, 2010: 164). Bunlarla birlikte işletmeler web sitesi reklamlarından olan bant veya banner reklamlar, affiliate, kenar çerçeveleri, zengin medya, ekran koruyucular, profil reklam, hiperlinkler, hedefli reklamlar, metin içi reklamlar, itme, küçük çaplı siteler ve açılan pencereler reklamlarını en iyi şekilde kullanmaları gerekmektedir (Öztürk, 2013).

İnternet tabanlı uygulamalar alanına giren bir diğer dijital reklam mecrası yeniden pazarlama reklamlarıdır. Yeniden pazarlama reklamları web sitesine girip hiçbir şey satın almadan çıkan kullanıcılara girdiği siteyle ilgili reklamlar göstererek bu kullanıcılarla tekrar bağlantı kurulmasına yardımcı olan bir reklam türüdür (Gökşin, 2017). Elektronik-posta reklamları ise, herhangi bir mamulü veya işletmeyi tanıtan mesajların internet ortamında müşterilerle paylaşılmasıdır. E-posta reklamları, marka tanınırı̆̆ını artırma, müşterilerle yakın ilişkiler kurma ve müşterileri yeni ürünler satın almaya teşvik etme açısından önemlidir (Mestçi, 2013: 36). Tüketiciler, kendilerini ilgilendiren dijital reklamlara yanıt vermeye daha yatkındırlar (Taylor, 2015:414).

Mobil iletişimin alt yapısının hızlı gelişimi ve insanların mobil cihazları kullanma alışkanlıklarının değişmesiyle beraber mobil uygulamalar da önemli bir reklam kanalı haline gelmiştir. Mobil uygulamalar dijital reklamcılığın bir alt kümesi olup kendi içinde farklı reklam kanalları içerir. Sms, Ems, Mms, Ivr, Video Ivr ve lokasyon-bazlı mesaj gönderimleri itme tipi mobil reklam mecralarının başında gelmektedir (Varnalı, 2013:77). Mobil uygulamalar iş fırsatlarını genişletmek ve kişisel üretkenliği geliştirmek anlamında sınırsız olanaklar sunmaktadır (Hopkins ve Turner, 2012: 81).

Dijital reklam uygulamalarının başarısında oyun hedefli reklamlar da öne çıkmaktadır. Bilgisayar oyunları içerisine yerleştirilmiş marka reklamları veya markalar için planlanmış özel oyunlar şeklinde yapılan reklamlar ve markanın, oyun içerisine büründüğü oyun senaryosu markaya uygun hazırlanmış oyun tabanlı reklamlar dikkat çekmektedir (Babacan, 2015: 342-343). Eğlence öğesiyle bir işletmenin markasının birleşerek tasarlandığı oyuniçi reklamlar sayesinde, bilgiler müşterinin hafızasından kolay kolay silinmemekte (Özdem, 2010:167), böylece markalar müşterilerinin hem eğlenmesini hem de markalarına olan bağııı̆ıını sürdürmeye çalışmaktadır. Oyunlaştırma örnekleri olarak "Nike+", "Yemek sepeti”, "Apple Watch" (kan grubunu, alerjiyi ve acil durumlarda ulaşılabilecek kişiyi kaydetmeyi sağlayan) karşımıza çıkmaktadır (Ertemel, 2016:152153). 
Sosyal medya araçları, reklam verenler için görsel reklamlar, içerik tanıtımları, çeşitli uygulamalar ve eklentiler sunması açısından önemlidir (Alhabas, 2017). Dijital reklam araçlardan biri olan sosyal ağlar: kişisel ağlar (facebook, forsquare, snapchat, instagram, path ve google+), içerik ağları (twitter, instagram, google+, pinterest,), ortak ilgi toplulukları (linkedin, flickr, youtube, meetup) olarak sınıflandırılmaktadır (Kuş, 2016: 49). Bu araçlar sayesinde reklamverenler müşterilerini daha yakından tanıma ve müşterilerine daha da yaklaşma şansı elde etmektedir. Sosyal medya araçları, sosyal medyadaki reklam iletilerini doğru hedef kitleye en kısa zamanda ulaştırma noktasında oldukça önemlidir. Bu bağlamda son zamanlarda markalar, özellikle sosyal ağlarda birbirleriyle sürekli iletişim ve etkileşim halinde olan bireylerin satın alma tercihlerinde etkili olabilmek, marka tanınırlığını ve farkındalığını artırabilmek amacıyla viral reklamcılık faaliyetlerini, e-etkileyiciler olarak adlandırılan sosyal medya fenomenleri ile gerçekleştirmektedirler. Çünkü bir etkileyici, diğer müşterilerin görüşlerini ve satın alma kararlarını önemli ölçüde etkileyen, bir marka temsilcisi görevini üstlenen üçüncü bir taraftır(Brown ve Hayes 2008).

\section{Araștırmanın Yöntemi}

Türkiye İstatistik Kurumunun (TÜIK) sonuçlarına göre, kişisel kullanım amacıyla bireylerin internet üzerinden sipariş verdiği ya da satın aldığı mal ve hizmet türlerinden olan giyimin 2013 yılsonu rakamlarına göre \%48,6 olduğu 2017 yılsonu rakamlarına göre \%62,3 olduğu görülmektedir (TÜIK, 02.08.2018). Internet üzerinden yapılan giyim alışverişlerinin oranının her geçen yıl arttığı görülmektedir. Buradan hareketle, giyim sektöründe, hedef kitleye hızlı ve etkin bir şekilde ulaşabilmek, müşteride marka bilinci oluşturabilmek, müşteri memnuniyeti sağlayabilmek amacıyla uygulanan pazarlama stratejileri ve kullanılan dijital reklamcılık araçlarının markalama sürecine etkisi yerel bir firma bağlamında tespit edilmeye çalışılmıştır.

Araştırmanın ana kütlesini Isparta'da kurulan yerel bir işletme iken ulusal bir işletme haline gelen ve markalaşan "Vavin" oluşturmaktadır. Isparta Süleyman Demirel Üniversitesi öğrencisi dört girişimci tarafından yerel bir firma olarak kurulan Vavin, 2013 yılında Isparta/Merkez'de doğmuş ve daha sonra ulusal bir marka haline gelmiştir. Vavin'in halen, internet mağazacılığı yanında Isparta, Antalya, Ordu, Van, Tatvan, Fethiye illeri olmak üzere 6 mağazası bulunmaktadır.

Vavin, internet üzerinden alışverişin henüz çok fazla yaygınlaşmadığı 2013’lerde ilk olarak mağazacılık sistemi ile ortaya çıkmıştır. Daha sonra Facebook üzerinden satış yapan farklı bir girişimciden esinlenerek, 2014 yılında dijital reklamcılık faaliyetlerine başlamışlardır. Dijital platformlar ve dijital reklamlar sayesinde kısa sürede satışlarını artıran Vavin daha sonra "vavin.com.tr" alan adı altında müşterilerine hizmet vermeye devam etmiştir. Vavin'in pazarlama stratejileri öncelikle kitleyi genişletebilmek, büyük pazara ulaşabilmek ve markalaşmak olmuştur. Sosyal medyada bir milyona yakın takipçi sayısına ulaşmayı kısa sürede başarmış; internet üzerinden 81 ile sipariş göndermeye başlamıştır. 
Araştırmada veriler, nitel araştırmalarda veri toplama yöntemi olarak en çok tercih edilen, yarı yapılandırılmış görüşme tekniği kullanılarak elde edilmiştir. Vavinyöneticileri ile görüşmeler, Isparta'da Mayıs ve Temmuz 2018'de yüz yüze; çeşitli zamanlarda dijital platformlar aracılığıyla gerçekleştirilmiştir. Elde edilen veriler işletme sahiplerinin vermiş olduğu bilgiler ve dijital platformlarda yayınlamış oldukları bilgilerle sınırıdır. Yöneticiye yüz yüze görüşmeye başlamadan önce araştırma konusunda bilgilendirme yapılmış; araştırma ile araştırmacıya güven ve başarılı bir iletişim ortamı oluşturulmaya çalışıımıştır. Bu da kurucunun yöneltilen sorulara doğru ve samimi cevaplar vermesini sağlamıştır.

Uygulanan dijital reklam stratejileri ve markalama sürecindeki rolünü belirlemeye yönelik, yöneticilere 5 adet açık uçlu soru sorulmuştur. Görüşmeler, 1-2 saat aralığındaki bir sürede gerçekleştirilmiş olup, yöneticilerin izni alınarak bilgilerin kaybolmaması için görüşmelerin ses kayıtları alınmıştır.

Vavin ile ilgili derlenen verilerin analizinde, nitel araştırma yöntemlerinden biri olan içerik analizi uygulanmıştır. Çözümlemede, teorik çerçeveye bağlı kalınarak 5 kategoride "Betimsel Analiz" gerçekleştirilmiştir. Analiz için ses kayıtları yazılı metin haline getirilmiş; teorik bağlamda kategoriler belirlenerek, mevcut verilerin bu çerçevede analizleri yapılmış ve anlam kolaylığı sağlanması açısından elde edilen bulgular tablolaştırılmıştır. Belirlenen kategoriler teoride belirtilen dijital reklam stratejileriyle sınırlıdır.

\section{Bulgu ve Yorumlar}

Vavin'in dijital reklamcılık stratejileri kapsamında kullandığı internet tabanlı reklam uygulamalarına ilişkin bilgiler ve örnekler Tablo 1'de görülmektedir. 
Tablo 1: Vavin'in Internet Tabanlı Reklam Uygulamaları

\begin{tabular}{|c|c|c|c|}
\hline Dijital Reklam Araçları & $\begin{array}{l}\text { Kullanılmaya } \\
\text { Bașlandığı Yıl }\end{array}$ & $\begin{array}{l}\text { Kullanım } \\
\text { Durumu }\end{array}$ & Örnekler \\
\hline $\begin{array}{l}\text { Arama Motoru Reklamları } \\
\text { (SEA) ve Arama Motoru } \\
\text { Optimizasyonu (SEO) }\end{array}$ & 2013 & $x$ & $\begin{array}{l}\text { Google AdWords reklamları ile SEA için belli } \\
\text { kelimelerde ilk sıralarda olmak hedefleniyor. } \\
\text { Bir kiși Kot Ceket almak için Google’a kot } \\
\text { ceket yazarsa sponsorlu olarak ilk sayfada } \\
\text { çıkmayı sağlanıyor. } \\
\text { SE0 optimizasyonu; } \\
\text { İki farklı koldan yapıılıyor birinci ve önemli } \\
\text { olan kısım site içi SEO bunun için ürün } \\
\text { linklerine anahtar kelimelerin uygun șekilde } \\
\text { yerleștirilmesi. } \\
\text { İkinci kısım olarak Site dıșı SEO bu } \\
\text { durumda ise müșterilerin doğru içeriğe } \\
\text { ulașmasını sağlamak amaç̦lı özgün içeriğin } \\
\text { olușturulması. } \\
\text { Örnek olarak; Blog siteleri ile özgün içerikler, } \\
\text { konu ile alakalı backlinkler, mikrobloglarda } \\
\text { konu ile ilgili backlinkler. }\end{array}$ \\
\hline $\begin{array}{l}\text { Yeniden Pazarlama } \\
\text { Reklamları }\end{array}$ & 2013 & $x$ & $\begin{array}{l}\text { Yeniden pazarlama için Google Adwords, } \\
\text { Facebook business'dan yararlanılmaktadır. } \\
\text { Vavin'in sitesinden herhangi bir ürün bakan } \\
\text { müșteriye bașka sitelerde dolașırken o ürünle } \\
\text { ilgili reklamlar gösterilerek hatırlatıır. } \\
\end{array}$ \\
\hline Web Sitesi Reklamları & 2013 & $x$ & $\begin{array}{l}\text { https://www.vavin.com.tr `de ürün bilgileri, } \\
\text { yüksek çözünürlüklü ürün görselleri } \\
\text { mankenlerle yapılan çekimler olarak } \\
\text { paylașıımaktadır. Doğrudan satıș imkânı } \\
\text { sunulmaktadır. }\end{array}$ \\
\hline $\begin{array}{l}\text { a. Görüntülü/banner } \\
\text { reklamlar }\end{array}$ & 2013 & $x$ & $\begin{array}{l}\text { Google Adwords aracılığı ile yapılan } \\
\text { reklamlardır. Haftalık 3-4 reklam kampanyası } \\
\text { bu șekilde kullanılmaktadır. 1080x1200 piksel } \\
\text { ölçüleri genelde kullanılmaktadır. }\end{array}$ \\
\hline
\end{tabular}




\begin{tabular}{|c|c|c|c|}
\hline b. Affiliate & 2016 & $x$ & $\begin{array}{l}\text { Aylık düzenli olarak sosyal medya hesapları } \\
\text { ve belirli bir komisyon karșilığı beğen, paylaș, } \\
\text { yorum yap kampanyaları ile ödüller-indirimler } \\
\text { tüketicilere sunulmuștur. }\end{array}$ \\
\hline c.Kenar çerçeveleri & 2013 & $x$ & $\begin{array}{l}\text { Facebook'ta müșteri kendi sayfası ile } \\
\text { ilgilenirken sağ ya da sol kenarda a/b testleri } \\
\text { içerisinde dönüșüm oranında sağ kenar } \\
\text { çerçevesi daha önde olduğu için bu tarafı } \\
\text { daha çok tercih edilmiștir. }\end{array}$ \\
\hline d. Zengin medya & 2014 & 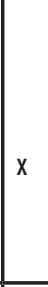 & $\begin{array}{l}\text { Kullanııının dolaștı̆ıı pencerenin arkasında } \\
\text { otomatik bir șekilde kendiliğinden } \\
\text { yüklenmesi ve reklamın görünürlüğüne } \\
\text { imkan vermesi. Bunun örneği ise çekimlerde } \\
\text { yapılan canlı yayınlar ve interaktif indirimler/ } \\
\text { kampanyaların görüntülenmesi }\end{array}$ \\
\hline g. Profil reklam & 2018 & $x$ & $\begin{array}{l}\text { Google Adwords, Facebook business. } \\
\text { Tablolar için yapılan çalıșmada Türk bayrağı, } \\
\text { Atatürk görselleri, Kurt ve Türk temalı } \\
\text { görseller ve buna uygun müzikle hedef kitle } \\
\text { olarak BÖRÜ dizisini seven, takip eden, } \\
\text { beğenen kitle seçilmiș bunun sonucunda } \\
\text { düșük maliyet yüksek dönüșüm alınmıștır. }\end{array}$ \\
\hline h.Metin içi reklamlar & 2016 & $x$ & $\begin{array}{l}\text { Blogların içerisine gizlenen anahtar } \\
\text { kelimelerle siteye trafik çekmek, } \\
\text { konu hakkında bilinçaltı olușturmak } \\
\text { ve markalamayı geliștirmek için } \\
\text { kullanılmaktadır. }\end{array}$ \\
\hline ı. Hedefli reklamlar & 2015 & $x$ & $\begin{array}{l}\text { Yapılan çalıșmalarla bazı anahtar kelimelerin } \\
\text { üst sıralara çıkması sağlanması için çeșitli } \\
\text { pozitif ve negatif kelimelerin süzülmesi } \\
\text { sonucu dönüșüm alınan kelime sayısı } 12000 \\
\text { kelimeden } 23000 \text { kelimeye çıkmıștır. Örneğin; } \\
\text { Genel bir ifade olan kadın kelimesi ile yapılan } \\
\text { aramalarda üst sıralarda olmak yerine, daha } \\
\text { detaylı kadın elbise kelimesinde üst sıralarda } \\
\text { olmak hedeflenmiștir. }\end{array}$ \\
\hline
\end{tabular}




\begin{tabular}{|c|c|c|c|}
\hline $\begin{array}{l}\text { j. Küçük çaplı siteler ve } \\
\text { açılan pencereler }\end{array}$ & 2015 & $x$ & $\begin{array}{l}\text { Herhangi bir sitede gezerken müșterinin } \\
\text { karșısına pop-up șeklinde büyük bir banner } \\
\text { ile hem marka bilinirliği hem de ürün } \\
\text { yönlendirme șeklinde kullanıımaktadır. } \\
\text { Șık kadın ve erkeğin uyumlu ve dikkat } \\
\text { c̦eken kompozisyon eșliğinde müșterileri } \\
\text { ıșığın büyüsüyle alıșverișe ikna etmek ic̦in } \\
\text { kullanılmıștır. }\end{array}$ \\
\hline E-Posta Reklamları & & - & \\
\hline
\end{tabular}

Vavin tarafından ilk olarak web sitesi reklamları, internet tabanlı reklam uygulamaları olan arama motoru reklamları ve arama motoru optimizasyonu, görüntülü reklamlar, kenar çerçeveleri, yeniden pazarlama reklamları kullanıldığı görülmüştür. Sonrasında ise zengin medya, hedefli reklamlar, metin içi reklamlar, profil reklamlardan yararlanılmıştır. Ayrıca Vavin'in müşterilerine e-posta reklamları aracılığı ile ulaşmadıkları görülmüştür.

Tablo 2: Vavin'in Mobil İçerikli Reklam Uygulamaları

\begin{tabular}{|c|c|c|c|}
\hline Dijital Reklam Araçları & $\begin{array}{l}\text { Kullanıımaya } \\
\text { Bașlandığı Yıl }\end{array}$ & $\begin{array}{l}\text { Kullanım } \\
\text { Durumu }\end{array}$ & Örnekler \\
\hline KIsa mesaj hizmeti (SMS) & 2015 & $x$ & $\begin{array}{l}\text { İzin veren müșteri dataları ile kampanya } \\
\text { bildirimleri, indirimli ürünler ya da sloganlarla } \\
\text { kullanılmaktadır. Örnek olarak 9-8'lik kampanya } \\
\text { sloganı ile 9.8 TL olan ürünlerin satıșı mesaj } \\
\text { yoluyla müșterilere iletilmiștir. }\end{array}$ \\
\hline $\begin{array}{l}\text { Coklu ortam mesaj hizmeti } \\
\text { (MMS) }\end{array}$ & & - & \\
\hline EMS & & - & \\
\hline $\begin{array}{l}\text { QR(Quick Reference) } \\
\text { Kodlar/ 2D Kod }\end{array}$ & & - & \\
\hline IVR & 2016 & $x$ & $\begin{array}{l}\text { Müșteri çağrı merkezine ulaștığında sesli } \\
\text { yanıt sistemi ile satıș temsilcisine veya sipariș } \\
\text { durumunu takip için Ivr sistemine yönlendirilir. } \\
\text { Ayrıca Vavin firması olarak müșterileri Ivr sistemi } \\
\text { ile arayarak ürün tanıtımı yapmıștır. }\end{array}$ \\
\hline Lokasyon-bazlı & 2016 & $x$ & $\begin{array}{l}\text { Müșteriler mağazada check-in yapıp bunu kasada } \\
\text { gösterdiklerinde alıșverișlerinde \%10 indirim } \\
\text { yapılmıștır }\end{array}$ \\
\hline
\end{tabular}




\begin{tabular}{|l|l|l|l|}
\hline $\begin{array}{l}\text { Yakın Saha Iletișimi (NFC) } \\
\text { ve Bluetooth }\end{array}$ & - & \\
\hline Whatsapp & 2016 & $\mathrm{x}$ & Whatsapp üzerinden sipariș imkanı sunulmaktadır. \\
\hline
\end{tabular}

Vavin mobil içerikli reklam uygulamaları olarak MMS, EMS, QR Kodlar, NFC, Bluetooth araçlarını kullanmamıştır. Bir takım indirimler veya kampanyalar müşterilere SMS yoluyla iletilmiştir. IVR ise maliyetli olduğu ve memnuniyet oranı açısından iyi sonuç alınamadığı için sonrasında bu yöntemden 2017 yılında vazgeçilmiştir. Günümüzün en popüler akıllı telefon uygulamalarından Whatsapp'ın da sipariş zincirine eklenmiş olması Vavin'in kendini yenileme kapasitesinin bir göstergesi olarak değerlendirilebilir.

Tablo 3: Vavin'in Oyun Hedefli Reklam Uygulamaları

\begin{tabular}{|c|c|c|c|}
\hline Dijital Reklam Araçları & $\begin{array}{l}\text { Kullanılmaya } \\
\text { Baslandığı Yıl }\end{array}$ & $\begin{array}{l}\text { Kullanım } \\
\text { Durumu }\end{array}$ & Örnekler \\
\hline $\begin{array}{l}\text { Advergame } \\
\text { (Eğlendirici reklam, Oyunlu } \\
\text { reklam) }\end{array}$ & 2017 & $x$ & $\begin{array}{l}\text { “Ramazan boyunca her gün } 100 \text { adet ürün } 1 \\
\text { TL” kampanyası için site içerisine saklanan } \\
\text { ürünleri müșterinin daha kolay bulabilmesi } \\
\text { için düzenlenen basit puzzlelar markanın } \\
\text { sosyal medya hesaplarında paylașılmıștır. } \\
\text { Puzzlelar olușturulurken ürün görseli } 9 \text { parçaya } \\
\text { bölünmüștür görselde yerleri değiștirilmiștir. } \\
\text { Görsel doğru hale getirildiğinde ürün resmi } \\
\text { ortaya çıkmaktadır. Bu sayede ürün ödül olarak } \\
\text { müșteriye sunulmaktadır. }\end{array}$ \\
\hline In-Game (Oyun icci Reklam) & & - & \\
\hline
\end{tabular}

Potansiyel müşterilerin ilgisini çekmek, yeni müşteriler kazanmak ve müşteri memnuniyetini artırmak adına müşterilere1 TL'ye ürün satın alabilme imkânı puzzle ile oyun haline getirilerek sunulmuştur. Bunun sonucunda internet sitesi günlük trafiği 15bin iken 50bine çıkmıştır ve satışların ciro oranı \%75 artmıştır. Bunun sebebi 1 TL'ye ürün alan bir müşterinin internet sitesinde gezinirken başka ürünler de satın almasından kaynaklandığı belirtilebilir. 
Tablo 4: Vavin'in Sosyal Medya İçerikli Reklam Uygulamaları

\begin{tabular}{|c|c|c|c|}
\hline Dijital Reklam Araçları & $\begin{array}{l}\text { Kullanılmaya } \\
\text { Bașlandığı Yıl }\end{array}$ & $\begin{array}{l}\text { Kullanım } \\
\text { Durumu }\end{array}$ & Örnekler \\
\hline \multicolumn{4}{|l|}{ Sosyal ağlar } \\
\hline Facebook & 2013 & $x$ & $\begin{array}{l}\text { https://www.facebook.com/vavincomtr } \\
877.090 \text { takipçi } \\
\text { Marka Bilinirliği } \\
\text { İnternet Sitesine Tıklamalar } \\
\text { İnternet Sitesi Dönüșümleri (üye olma, form doldurma, } \\
\text { ürün satın alma) } \\
\text { Uygulama İndirme Kampanyaları } \\
\text { Potansiyel Müșteriler Bulma } \\
\text { Reklam ve post paylașma } \\
\text { Sayfanın mesaj bölümünden sipariș imkanı }\end{array}$ \\
\hline Google+ & 2017 & $x$ & $\begin{array}{l}\text { https://plus.google.com/+vavincomtr } \\
25 \text { takipçi } \\
\text { İçerik paylașımı ürün ve blog postları } \\
\text { \#vavin \#vavingiyim \#moda \#istanbul \#ankara } \\
\text { \#erkekgiyim \#bayangiyim }\end{array}$ \\
\hline \multicolumn{4}{|l|}{ Sosyal imleme siteleri } \\
\hline Pinterest & 2015 & $x$ & $\begin{array}{l}\text { https://tr.pinterest.com/vavincomtr/ } \\
84 \text { takipçi } \\
\text { SEO ve Reklam amaçlı ürün görselleri }\end{array}$ \\
\hline \multicolumn{4}{|l|}{ Forsquare } \\
\hline Snapchat & 2016 & $x$ & $\begin{array}{l}\text { Müșteriler Snapchat uygulamasında paylaștıkları } \\
\text { ürünlerin ekran görüntüsünü alıp kasada göstererek } \\
\text { ödeme sırasında } \% 20 \text { indirim kazanıyor. }\end{array}$ \\
\hline \multicolumn{4}{|l|}{$\begin{array}{l}\text { Fotoğraf/ video/ müzik } \\
\text { paylașım siteleri }\end{array}$} \\
\hline Youtube & 2014 & $x$ & $\begin{array}{l}\text { https://www.youtube.com/watch } \\
303 \text { abone } \\
\text { Ürün tanıtımları içeren videolar } \\
\text { Açıklayıcı videolar (Haftalık kombin önerileri, } \\
\text { İlkbahar-yaz koreasyonları, Sokak Röportajları, Ana } \\
\text { Akım Medyada Vavin) }\end{array}$ \\
\hline
\end{tabular}




\begin{tabular}{|c|c|c|c|}
\hline Dijital Reklam Araçları & $\begin{array}{l}\text { Kullanılmaya } \\
\text { Bașlandığı Yıl }\end{array}$ & $\begin{array}{l}\text { Kullanım } \\
\text { Durumu }\end{array}$ & Örnekler \\
\hline Instagram & 2014 & $x$ & $\begin{array}{l}\text { https://www.instagram.com/vavincomtr/ } \\
13.436 \text { gönderi- 213bin takipçi } \\
\text { Ürün tanıtımı, doğrudan sipariș olanağı, görsel yoğun } \\
\text { paylașımlar, konu bașlığ//Etiketleme (hashtag) } \\
\text { kullanımı } \\
\text { \#vavin \#vavingiyim \#moda \#erkekgiyim \#bayangiyim } \\
\text { \#vavinblog \#vavincomtr \#tarzgiyim \#indirim vb. }\end{array}$ \\
\hline \multicolumn{4}{|l|}{ Bloglar } \\
\hline Șirket blogları & 2018 & $x$ & $\begin{array}{l}\text { https://blog.vavin.com.tr/ } \\
\text { Kadın, erkek, moda, alıșveriș ve makyaj kategorilerine } \\
\text { ilișkin güncel bilgi ve öneriler yüksek çözünürlüklü } \\
\text { görseller eșliğinde sunulmaktadır. }\end{array}$ \\
\hline \multicolumn{4}{|l|}{ Mikroblog } \\
\hline Twitter & 2015 & $x$ & $\begin{array}{l}\text { https://twitter.com/vavincomtr } \\
\text { Ürün tanıtımı amaçlı yüksek çözünürlüklü görsel } \\
\text { paylașımları } \\
\text { Diğer sosyal medya araçlarına bağlantılar } \\
\text { Doğrudan sipariș imkanı } \\
\text { \#vavin \#vavingiyim \#moda \#istanbul \#ankara } \\
\text { \#erkekgiyim \#bayangiyim }\end{array}$ \\
\hline \multicolumn{4}{|l|}{ Forumlar } \\
\hline Kızlarsoruyor.com & 2015 & $x$ & Müșteri kitlesine ulașma, deneyimlerin paylașımı \\
\hline $\begin{array}{l}\text { forumdonanımhaber. } \\
\text { com }\end{array}$ & 2015 & $x$ & $\begin{array}{l}\text { Müșteri ilișkileri yönetimi amacıyla (Șikayet ve } \\
\text { önerileri dinlemek) } \\
\text { Deneyim paylașımı }\end{array}$ \\
\hline \multicolumn{4}{|l|}{ Profesyonel ağlar } \\
\hline Linkedin & 2016 & $x$ & $\begin{array}{l}\text { https://tr.linkedin.com/company/vavin.com.tr } \\
16 \text { takipçi } \\
\text { Vavin hakkında genel bilgiler }\end{array}$ \\
\hline Viral reklamlar & & - & \\
\hline
\end{tabular}

Vavin markası Facebook reklamları kapsamında reklam tıklamalarına bağlı olarak karlılık sağlanan ve ana reklam şekli olarak kullandığı "İnternet sitesi dönüşümleri" ne \%65 oranında bütçe ayırmaktadır. Daha çok müşteriye bilgi vermek, kampanya duyurularını yapmak ve Seo gelişimini sağlamak için bloglar ve haber sayfaları kullanılarak bütçenin \%10 luk kısmı "Internet sitesine tıklamalar" reklamlarına 
yatırılmıştır. Daha çok ana akım medya dönemlerinde marka bilinirliğinin desteklenmesi için \%5 reklam bütçesi "Marka bilinirliği reklamları"na yatırılmıştır. Sosyal medya içerikli reklamlar kapsamında reklam yatırımlarının önemli bir kısmının facebook reklamlarına yöneltildiği görülmektedir. Sosyal medya içerikli reklamlarda profesyonel çekimlerle ürünlerin yüksek çözünürlüklü görsellerine yer verilerek doğrudan satış imkanı sunulmaktadır. Ayrıca 2015 yılında "Pinterest" kullanımı çok yaygın değilken bile Vavin'in bu dijital reklam aracını fark etmeleri, hashtag (\#)kullanmaları vb. diğer dijital reklam uygulamalarını da etkin bir şekilde kullanmaları Vavin'in markalaşmasında etkili olmuştur.

Vavin, sosyal medya platformlarında günlük paylaşımlar yaparak bu paylaşımların formatlarını aylık olarak değiştirmektedir. Paylaşımlar video veya slaytlarla çeşitlendirilmekte ayrıca kampanya dönemlerinde banner, sliderlar hazırlanarak müşteriye yenilik hissi verilmektedir. İnternet sitesi için tamamen güncellemeler ise 20 günde bir yapılmaktadır.

Vavin teknolojik yenilikleri kullanma bakımından yerel bazda öncü bir firma olarak değerlendirilebilir. Rogers'ın Yeniliğin Yayılımı Kuramı bağlamında bakıldığında yeniliklerin benimsenmesi açısından hem yenilikçi hem de erken benimseyenler grubunda yer almaktadır (Orr, 2003, 2). Firma kurulmasılla birlikte web sitesi reklamlarını, banner reklamları, arama motoru reklamlarını, Facebook reklamlarını, youtube videolarını ve instagram reklamlarını marka iletişim stratejilerinde kullanması açısından yenilikçi; 2015 yılından sonra twitter reklamları, pinboardlar, forumlarda yer alma, whatsupp uygulamaları, lokasyon bazlı uygulamalar ve oyun reklamlarını iletişim sürecinde aktif bir şekilde kullanması ve platformların yaygın kullanıma açılması itibariyle değerlendirildiğinde de erken benimseyenler grubunda yer almaktadır. Bu deneyimlerinin sonucunda, 2017 yılında E-ticarete yeni başlayacak firmalara bilgi ve deneyimlerini aktarmak amacıyla kurdukları E-adam isimli danışmanlık şirketi de teknoloji erken benimseyenler grubunda yer aldığını işaret etmektedir.

Tablo 5: Vavin'de Markalama Sürecine Etki Eden Diğer Unsurlar

\begin{tabular}{|c|c|c|}
\hline $\begin{array}{l}\text { Markalama sürecine etki } \\
\text { eden diğer unsurlar }\end{array}$ & $\begin{array}{l}\text { Kullanılmaya } \\
\text { Bașlandığı Yıl }\end{array}$ & Örnekler \\
\hline Müșteri odaklılık & $2013 \ldots$ & $\begin{array}{l}\text { Kargonun sipariș sürecinde müșterilerinin bilgilendirilmesi, } \\
\text { müșterilerin istek ve șikâyetlerine hızlı geri bildirim sağlamaları, } \\
\text { uygun fiyat sunumu, en iyi lokasyonlarda ve etkileyici mağaza } \\
\text { atmosferinde ürün sunumu, müșteriye uygun içerik üretimi, } \\
\text { müșteriye özel kampanya, indirimler ve kuponlar sağlanması, } \\
\text { ambalajlama ve etikete önem verme, hediye gönderimi, müșteriye } \\
\text { özel tablolar yapılması, Kargo içerisine Vavin logolu oda kokuları } \\
\text { ve gül lokumu paketlerinin konulması }\end{array}$ \\
\hline
\end{tabular}




\begin{tabular}{|l|l|l|}
\hline $\begin{array}{l}\text { Tanıtımda profesyonel } \\
\text { isimlerle çalıșma }\end{array}$ & 2016 & Tuğba Özay (Ünlü kullanımı- Star faktörü) \\
\hline $\begin{array}{l}\text { Sosyal medya fenomenleri } \\
\text { ile çalıșma }\end{array}$ & 2016 & Ekin Soyak (Kanaat önderi) \\
\hline $\begin{array}{l}\text { Sosyal sorumluluk } \\
\text { projeleri ve Sponsorluk } \\
\text { faaliyetleri }\end{array}$ & $2015-2017$ & $\begin{array}{l}\text { Sponsorluk (Esra Erol'la Evlen Programı) } \\
\text { Davraz Kayak Merkezi, Isparta Gül bahçelerinin ve Lavanta } \\
\text { bahçelerinin tanıtımını } \\
\text { Isparta Gül bahçelerinde ve Lavanta bahçelerinde gerçekleștirilen } \\
\text { çekimlerin Fox Ana Haber Bülteninde yayınlanması }\end{array}$ \\
\hline Ana akım medya desteği & 2017 & $\begin{array}{l}\text { Dijital reklamların yanında Ulusal Basında Televizyon reklamlarının } \\
\text { yayınlanması } \\
\text { Yerel basında Vavin markası hakkında yapılan röportaj (Isparta } \\
\text { Kanal 32). }\end{array}$ \\
\hline Geniș ürün yelpazesi & 2017 & $\begin{array}{l}\text { Google’da tüketicilerin çok fazla dekorasyon tablo aramaları } \\
\text { dikkate alınarak “Tablo” ürün kategorisi olușturulmuștur. Ayrıca } \\
\text { kișiye özel tablolar tasarlanmıștır }\end{array}$ \\
\hline Danıșmanlık hizmeti & 2017 & $\begin{array}{l}\text { E-adam isimli danıșmanlık șirketi kurmușlar bu sayede E-ticarete } \\
\text { yeni bașlayacak olanlara bilgi ve deneyimlerini aktarmaktadırlar. }\end{array}$ \\
\hline Toptan satıș & 2016 & $\begin{array}{l}\text { Hem son tüketiciye hem perakendecilere hitap ederek dağı̆ıım ağını } \\
\text { genișletmektedir. }\end{array}$ \\
\hline Xml bayiliği & $\begin{array}{l}\text { Bir firmanın veya herhangi bir kișinin, Vavin markasının web sitesi } \\
\text { üzerinden satıșlarını gerçekleștirmesidir. }\end{array}$ \\
\hline
\end{tabular}

Vavin Giyimin markalama sürecinde etkili olan temel unsur dijital reklamları etkin bir şekilde kullanmalarıdır. Bununla birlikte markalama sürecine etki eden diğer unsurlar ise; müşteri odaklı çalışılması, ana akım medya desteği, profesyonel isimlerle çalışııması, sosyal medya fenomenleriyle çalışılması, sosyal sorumluluk projeleri ve sponsorluk faaliyetleri gerçekleştirilmesi, ürün yelpazesinin genişletilmesi, danışmanlık şirketi kurulması, Xml bayiliği ve toptan satış faaliyetleri gerçekleştirilmesidir.

Vavin markasının dijital reklamlara ve ana akım medyaya ayırdıkları bütçeye bakıldığında aylık ortalama 80-100 bin TL bütçe dijital reklamlara ayrılmaktadır. Dijital reklamlar ağırlıklı olmak üzere Ana akım medya ile dijital reklamların birbirini tamamlayacak şekilde kullanıldığı belirlenmiştir. Bu sebeple ana akım medya reklam kampanya dönemlerinde dijital reklam maliyetleri de yaklaşık olarak \%40 oranında artış göstermektedir.

Ana akım medya reklamları, reklam hazırlama maliyetleri ve reklam yayınlama maliyetleri olarak iki kısımda incelenmektedir. İlk olarak reklam filmi yapım aşaması için 150 bin TL harcanmıştır. İkinci olarak 600 bin TL yayınlanma maliyeti olmuştur. $\mathrm{Bu}$ maliyetlerin dönüşümleri Dijital reklam ve Ana akım medya reklam kanallarına 
pozitif olarak yansımıştır. Aylık olarak elde edilen ortalama 30-35 bin TL ciro reklamın yayınlandığı süre boyunca 60-70 bin TL dolaylarına çıktığı belirtilmiştir. Ana akım medya reklam kampanyası sürecinde dijital kanallar (Facebook, Instagram, Twitter Gibi Sosyal Medya Platformları;Yandex, Bing, Google gibi arama motorları vb.) internet sitesi trafiği ve arama motorlarındaki aranma hacmi pozitif olarak etkilenmiştir.Ayrıca, ana akım medyada bir aylık kampanya sürecinin sonunda yaklaşık olarak sadece \%20'lik bir düşüş ile satışlar devam etmiştir. Ana akım medya reklamlarının en önemli faydası ROi (yatırımın geri dönüşümü) değerlerini artırmasıdır. Kullanılan reklam platformları birbirini destekler nitelikte olduğu için reklam performanslarının ölçümlenmesinde çok büyük bir kıyaslama yapılamamaktadır.

\section{Sonuç}

Bu çalışmada yerel bir işletme olarak faaliyet gösteren Vavin' in ulusal bir işletme haline gelerek markalaşmasında etkili olan unsurlar ve kullanılan dijital reklam araçları incelenmiştir. Bu çalışmada işletmenin kurumsal yönetim ve finansal performansı analize dahil edilmemiş olup dijital reklamcılık uygulamaları değerlendirilmiştir.

İletişim ve tanıtım amaçlı olarak ilk facebook reklamlarını kullanmaya başlayan Vavin, 3 aylık ölçümleme ile yapılan değerlendirmeler sonucunda web sitesini oluşturmuştur. İlk etapta yapılan dijital reklamlar tek kanallı facebook üzerinden devam ederken elde edilen tecrübe doğrultusunda dijital reklam araçlarına ilgi ve kullanım düzeyi artmaya başlamıştır. Bu süreç içerisinde kullanılan reklam stratejileri ile geniş müşteri kitlesine ulaşılmıştır. Fakat belirli bir süreden sonra yeni müşteri ihtiyacını karşılamak amacı ile ana akım medya (televizyon, radyo, gazete, dergi, sinema vb.) desteği de alınarak daha geniş kitlelere ulaşma amacıyla hareket edilmiştir. Dijital reklam uygulamaları ile ana akım medya birbirini destekleyen uygulamalar olarak karşımıza çıkmaktadır. Dijital platformların, dijital reklamcılık faaliyetlerinin etkin bir şekilde kullanılarak ana akım medya ile desteklenmesi ve müşteri memnuniyetine önem verilmesi sonucunda Vavin, kısa sürede büyüme göstermiştir. Elde edilen ciroya ilişkin rakamlar bunu işaret etmektedir.

Markalama sürecine etki eden diğer unsurlar; müşteri memnuniyeti ve uygun fiyat sunumu, nitelikli görseller paylaşmaları, profesyonel isimlerle çalışmaları, sosyal medya fenomenleri ile çalışmaları, sosyal sorumluluk projeleri ve sponsorluk faaliyetleri gerçekleştirmeleri, Xml bayiliği ve toptan satış gerçekleştirmeleri, danışmanlık şirketi kurmaları, geniş ürün yelpazesine sahip olmaları, ana akım medya desteği olarak karşımıza çıkmaktadır.

Dijital reklam araçları kullanılmaya başlamadan önce verilmesi gereken en önemli kararlardan biri seçilecek reklam tipidir. Dijital reklamcılık araçları olarak Vavin markası tarafından; İnternet tabanlı reklam uygulamalarının, Sosyal medya içerikli reklam uygulamalarının ve Oyun hedefli reklam uygulamalarının etkin bir şekilde kullanıldığı görülürken Mobil içerikli reklam uygulamalarının diğer araçlara göre daha sınırlı kaldığı tespit edilmiştir. Kullanılan dijital reklam uygulamalarının; marka bilinirliği, erişim, 
trafik, etkileşim, uygulama yüklemeleri, video görüntülemeleri, potansiyel müşteriler bulma, ürün kataloğu satışları, dönüşümler, mağaza ziyaretlerinde artışa yol açtığı görülmektedir.

\section{Kaynakça}

Alhabas, S.,MundedJ. ve Syed, H.A. (2017).Social Media Advertising: UnravelingTheMystery Box, ShellyRodgers, EstherThorson(Ed.).Dijital AdvertisingTheoryandResearch Third Edition içinde (s. 285-300). New York: Routledge.

Aslan, A. (2017). Sosyal Ağlar ve Online (Çevrimiçi) Reklam Üzerine Bir Değerlendirme.1. Uluslararası İletişimde Yeni Yönelimler Konferansı,230-235, İstanbul:

Aslantaş, A. (2013).Seo ve Sem, İstanbul: Pusula Yayıncllık,

Babacan, M. (2015). Nedir Bu Reklam?, Istanbul: Beta Yayıncılık.

Barışkan, G. (2015). SEO 2015, İstanbul: Dikeyeksen Yayıncılık.

Berman, S.J. (2012). Digital Transformation: Opportunities To Create New Business Models.

Strategy and Leadership, 40(2), 16-24.

Brown,D. ve Hayes, N. (2008). Influencer Marketing:Who Really Influences Your Customers?, Amsterdam, Netherlands: Routledge,

Chaffey, D. ve Smith, P.R. (2013). E-Marketing Excellence: Planning and Optimizing YourDigital Marketing. Routledge.

Çıvgın, A. (2018). "Dijital Reklamcılık" https://www.ruzgardijital.com/blog/dijital-reklamciliginonemi-gun-gectikce-artiyor/ (Erişim tarihi: 02.08.2018).

Deloitte (2018). Medya ve Reklam Yatırımları Reklamcılar Derneği Raporu 2017,https://www2. deloitte.com/content/dam/Deloitte/tr/Documents/technology-mediatelecommunications/RD\%20 Medya\%20ve\%20Reklam\%20Yatirimlari\%202017\%20Raporu.pdf (Erişim Tarihi: 10.08.2018)

Davis, F. D. (1989). Perceived usefulness, perceivedease of use, and user acceptance of information technology. MIS quarterly, 319-340.

Elden, M. ve Makal D. (2014).AlexBogusky: Dijital Çağda Reklam ve Reklamcılık, Müge Elden ve UğurBatı (Ed.), Reklam Ustaları 1 içinde (s.437-466). Ankara: Detay Yayıncılık.

Ertemel, A.V. (2016). Dijital Çağda İllüzyonel Pazarlama, İstanbul: Abaküs Yayınları.

Gökşin, E. (2017). Dijital Pazarlama Temelleri, İstanbul: Abaküs Yayınları.

Hopkins, J. ve TurnerJ. (2012). Mobil Pazarlama Hakkında Her Şey, Çev: Başak Gündüz, İstanbul:Optimist Yayıncılık.

Kuş, O. (2016). İçerik Pazarlama: Dijital Dünyada Marka ve Hikaye Yaratma Stratejileri, İstanbul: Pales Yayınları.

Lombard, M. ve Synder-Duch J.(2017).DigitalAdvertising in theDigital Age:ThePower of (Tele) Presence,ShellyRodgersandEstherThorson (Ed.).DigitalAdvertisingTheoryandResearch, içinde 
(s.169-188) . New York: Routledge.

MeermanScott, D. (2010). Global Tezahürat, Çev: Levent Göktem, İstanbul:Mediacat.

Mestçi, A. (2013). İnternette Reklamcılık, İstanbul:Pusula Yayıncılık.

Orr, G. (2003). Diffusion of innovations, by Everett Rogers (1995). Retrieved January, 21, 2005.

Özdem, O.Ö (2010).Web Tasarımı Teknolojisinin İnternet Reklamcıı̆ı̆na Yansımaları, Sinem Yeygel Çakır(Ed.), Teknolojinin Pazarlama İletişimine Etkileri içinde (s. 165-183). Ankara:Nobel Yayıncılık.

Özkundakçı, M. (2012).Üçü Bir Arada, İstanbul:Hayat Yayıncılık.

Öztürk, R. G. (2013).Dijital Reklamcılık ve Gençlik, İstanbul:Beta Yayıncılık.

Rogers, E. M. (2003). The diffusion of innovation 5th edition.

Ryan D. andJonesC. (2009). UnderstandingDigital Marketing: Marketing StrategiesForEngagingTheDigitalGeneration, London:KoganPage.

Sevinç, S.S. (2012). Pazarlama Illetişiminde Sosyal Medya, İstanbul: Optimist Yayınları.

Sutherland, M. ve Sylvester, A. (2004). Reklam ve Tüketici Zihni, Çev: İ. Kalınyazgan, İstanbul: Mediacat.

Taylor,C.R. (2015).TheSixPrinciples of DigitalAdvertising, International Journal of AdvertisingTheQuarterlyReview of Marketing Communications, 28(3).

Thorson, E.,Rodgers, S. ve Tham, S. M. (2017).

TrendsandOpportunitiesforDigitalAdvertisingResearch: A Content Analysis of Advertising Age, 2000-2015,DigitalAdvertising içinde(s.61-74), New York: Routledge.

Truong, Y. veSimmons, G. (2010). Perceivedlntrusiveness in DigitalAdvertising: Strategic Marketing Implications.Journal of Strategic Marketing, 18(3), 239-256.

TÜIK (Türkiye İstatistik Kurumu) (2016). Kişisel Kullanım Amacıyla Bireylerin İnternet Üzerinden Sipariş Verdiği ya da Satın Aldığı Mal ve Hizmet Türlerinden İnternet Kullanımı http://www.tuik. gov.tr/PreTablo.do?alt_id=1028 (Erişim Tarihi: 02.08. 2018).

Varnalı, K., Toker A. ve Yılmaz C. (2011). Mobile Marketing Fundamentals andStrategy, USA:McGrawHill.

Varnalı, K. (2013). Dijital Tutulma: Pazarlama İletişimi ve İnsan, İstanbul:Mediacat Yayınları.

Yılmaz, R. ve Erdem M.N. (2016). 150 Soruda Geleneksel ve Dijital Reklamcılık, İstanbul:Umuttepe Yayınları. 